\title{
Citra Perempuan dalam Drama Pelacur dan Sang Presiden dan Relevansinya pada Pembelajaran Sastra
}

\author{
${ }^{1}$ Indra Perdana ${ }^{*}{ }^{2}$ Atikah Ani \\ Pendidikan Bahasa dan Sastra Indonesia, Universitas Palangka Raya \\ Pos-el: ${ }^{1}$ indra.perdana@fkip.upr.ac.id \\ 2anisatikah151998@gmail.com
}

Pengiriman: 22/04/2020; Diterima: 12/11/2020; Publikasi: 23/11/2020

DOI: $10.31629 /$ jermal.v1i2.2185

\begin{abstract}
Abstrak
Penelitian ini mendeskripsikan Citra Perempuan dalam naskah drama Pelacur dan Sang Presiden karya Ratna Sarumpaet dengan menggunakan kajian sastra feminis dan mendeskripsikan bahan ajar pada mata pelajaran bahasa Indonesia di Sekolah Menengah Atas. Metode penelitian yang digunakan dalam penelitian ini adalah pendekatan kualitatif metode deskriptif. Teknik pengumpulan data yang digunakan berupa teknik dokumentasi dan teknik pustaka. Sumber data dalam penelitian ini adalah drama Pelacur dan Sang Presiden. Hasil penelitian ini ditemukan bentuk-bentuk ketidakadilan gender dalam naskah drama Pelacur dan Sang Presiden yang terdapat dalam beberapa bagian yang meliputi: (1) bentuk ketidakadilan gender dari aspek perempuan sebagai objek dan citra diri, (2) bentuk ketidakadilan gender dari aspek perempuan menurut pandangan orang lain, (3) bentuk ketidakadilan gender dari aspek kekerasan dan tidak bernilai, dan (4) ketidakadilan gender dari aspek beban kerja ganda atau perempuan sebagai objek utama. Hasil analisis dari naskah drama Pelacur dan Sang Presiden karya Ratna Sarumpaet sudah memenuhi kriteria untuk dijadikan sebagai alternatif bahan ajar pada mata pelajaran Bahasa Indonesia di Sekolah Menengah Atas. Beberapa aspek untuk memilih bahan pengajaran sastra dengan tepat yaitu dilihat dari segi bahasa, psikologi, dan latar belakang budaya yang terdapat pada naskah drama Pelacur dan Sang Presiden karya Ratna Sarumpaet.
\end{abstract}

Kata Kunci: bahan ajar, feminisme, ketidakadilan gender, naskah drama PSP.

\begin{abstract}
This study aims to describe gender injustice in Ratna Sarumpaet's The Woman and The President play script by using feminist literary studies and describing teaching materials in literary criticism in college. The research method used in this research is a descriptive qualitative approach. Data collection techniques used in the form of documentation techniques and library techniques. The data source in this study is the play script The Woman and The President. The results of this study found forms of gender injustice in the novel The Woman and The President contained in several sections which include: (1) forms of gender injustice from the aspect of woman as objects and self image, (2) forms of gender injustice from woman in the eyes of others, (3) forms of injustice gender from the aspect of violence and wortless, (4) gender injustice from the aspect of multiple workloads woman as the main object. The results of the analysis of the naskah drama Pelacur dan Sang Presiden by Ratna Sarumpaet already meet the criteria to be used as an alternative teaching material in the Literary Criticism course in college. Some aspects of choosing literary teaching materials appropriately are seen in terms of language, psychology, and cultural background contained in the naskah drama Pelacur dan Sang Presiden by Ratna Sarumpet.
\end{abstract}

Key Words: Teaching materials, feminism, gender injustice, The Woman and The President Play Script. 


\section{PENDAHULUAN}

Di kehidupaan sehari-hari perempuan selalu dinilai memiliki kelas yang lebih rendah dari pada laki-laki. Perempuan dianggap sebagai makhluk yang lemah sehingga harus berada di bawah kekuasaan laki-laki. Hal ini yang mengakibatkan timbulnya pembedaan perlakuan terhadap kaum perempuan baik di lingkup masyarakat, sampai dalam lingkungan keluarga. Pengaruh konsep sosialisme mengatakan bahwa perempuan merupakan suatu kelompok dalam suatu masyarakat yang ditindas oleh kelompok lain, yaitu laki-laki (Djajanegara, 2003: 1).

Pendekatan feminisme dalam kajian sastra sering dikenal dengan kritik sastra feminisme. Feminis, menurut Ratna (2004:226), berasal dari kata femme yang berarti perempuan. Sugihastuti (2005:18) berpendapat bahwa feminisme adalah gerakan persamaan antara laki-laki dan perempuan di segala bidang baik politik, ekonomi, pendidikan, sosial dan kegiatan terorganisasi yang mempertahankan hakhak serta kepentingan perempuan. Feminisme juga menurut Sugihastuti merupakan kesadaran akan penindasan dan pemerasan terhadap perempuan dalam masyarakat, baik di tempat kerja dan rumah tangga.

Keluarga menjadi tempat pertama kali terjadinya masalah gender. Hal ini dipermasalahkan, karena secara sosial telah melahirkan perbedaan peran, tanggung jawab, hak, dan fungsi serta ruang aktivitas laki-laki dan perempuan dalam masyarakat. Perbedaan tersebut akhirnya membuat masyarakat cenderung membeda-bedakan dan pilih-pilih perlakuan akan akses, partisipasi, serta kontrol dalam hasil pembangunan laki-laki dan perempuan. Misalnya persoalan gender yang terjadi dalam keluarga seperti peran-peran yang tidak seimbang antara anggota keluarga laki-laki dan perempuan seringkali memposisikan laki-laki lebih mendapatkan hak-hak istimewa, sedangkan perempuan sebagai kaum kelas kedua, meskipun pada kelompok masyarakat tertentu hubungan yang dibangun antara laki-laki dan perempuan sudah lebih baik. Namun, jika ditelaah lebih jauh, pada sebagian besar kelompok masyarakat lainnya, hubungan yang seimbang antara laki-laki dan perempuan masih jauh dari harapan.

Selain di dalam lingkungan keluarga, posisi perempuan di bidang pendidikan dan lingkungan pekerjaan juga menjadi pilihan terakhir untuk mendapatkan layanan yang layak bagi perempuan. Oleh karena itu, di bidang pendidikan banyak perempuan yang tidak pernah mengenyam pendidikan atau buta huruf. Sementara itu di lingkungan pekerjaan, perempuan dianggap lemah, pasif, dan bergantungan kepada laki-laki, maka dari itu pemilihan pekerjaan masih berbasis gender, sehingga perempuan yang memiliki pendidikan yang tinggi pun tidak mendapatkan pekerjaan yang layak, seperti pekerjaan di bidang pelayanan jasa dan pekerjaan yang tidak banyak keterampilan, hanya sedikit perempuan saja yang menduduki jabatan sebagai manajer atau pengambil keputusan.

Permasalahan tersebut menyebutkan bahwa perempuan hanya berfungsi sebagai orang biasa pengatur rumah tangga yang harus mengerjakan segala pekerjaan yang ada di rumah saja dan tidak memiliki keahlian di bidang lain. Dengan demikian, konsep tersebut harus diubah. Sudah waktunya perempuan dan laki-laki samasama berfungsi dalam bidang yang sama tanpa adanya batasan-batasan baik itu di lingkungan keluarga, pendidikan dan pekerjaan, maka dari itu perempuan juga harus mendapatkan kesempatan yang sama memilih dan meraih posisi yang sejajar dengan laki-laki di bidang sosial.

Selain itu, dalam kehidupan seharihari sering terjadi ketimpangan perlakuan, contohnya kekerasan yang sering terjadi pada perempuan, perempuan diangap 
lemah, terjadinya pelecehan seksual, munculnya cinta sesama jenis, dan lain sebagainya (Faqih, 2013: 26) . Berbagai bentuk ketimpangan ini dapat dijumpai dalam sebuah karya sastra. Salah satu contoh karya sastra yang terdapat masalah gender adalah naskah drama yang menceritakan tentang kehidupan sosial.

Permasalahan tersebut tidak akan terjadi jika ada keadilan dan kesetaraan hubungan antara laki-laki dan perempuan dalam kehidupan bermasyarakat. Perempuan sering mengalami ketidakadilan gender dalam pergaulan sosial, hal tersebut yang membangkitkan kesadaran terhadap kaum perempuan untuk melakukan usaha-usaha demi tercapainya kesetaraan gender (Purwanto, 2016).

Seperti yang sudah dipaparkan di atas, ketidakadilan gender tidak hanya terjadi dalam kehidupan sehari-hari saja, tetapi juga terjadi di dalam dunia sastra. Sapardi (1979: 1) memaparkan bahwa sastra adalah lembaga sosial yang menggunakan bahasa sebagai medium. Sastra menampilkan gambaran kehidupan, dan kehidupan itu sendiri adalah suatu kenyataan sosial. Salah satu karya sastra yang mengangkat masalah gender yaitu naskah drama Pelacur dan Sang Presiden karya Ratna Sarumpaet yang diterbitkan dan pertama kali ditayangkan pada tahun 2009 oleh Satu Merah Panggung, di Jakarta pada tahun 2009, dengan tebal 119 halaman.

Drama ditulis dengan menggunakan dialog. Drama juga merupakan permainan simbol-simbol kehidupan yang ada (Endraswara 2012:14). Tidak ada drama yang disampaikan secara terang-terangan, semua cerita dalam naskah drama menggunakan simbol-simbol yang dapat dimengerti penikmat sastra. Kemudian untuk menganalisis drama tersebut maka naskah tersebut dibedah (Fahmi 2017).

Naskah Drama tersebut mengangkat kehidupan tokoh perempuan dalam kaitannya dengan perdagangan anak saat itu untuk diperdagangkan karena keadaan ekonomi. Menurut Waluyo (2003: 14) dan Nurgiyantoro (2015: 248) penokohan berhubungan dengan perwatakan. Meliputi masalah siapa tokoh dalam cerita, bagaimana perwatakan dan bagaimana penempatan serta pelukisannya dalam sebuah cerita sehingga dapat memberi gambaran yang jelas kepada pembaca.

Naskah Drama Pelacur dan Sang Presiden juga menceritakan tentang perempuan yang memiliki ketidakberdayaan dalam hal pendidikan atau kehidupannya pada saat itu, perempuan yang seharusnya dijaga dan dihormati pada saat itu malah diperdagangkan ke mucikari demi menyambung hidup. Perempuan yang dihukum mati dan tidak mendapat pembelaan apapun karena persoalan hidup pada masa itu. Naskah drama ini juga menceritakan sosok perempuan yang menjadi pembicaraan orang banyak yang memiliki kaitan dengan kehidupan masa kini serta dipandang bermanfaat untuk menata kehidupan masa depan yang lebih baik, khususnya bagi perempuan.

Sudah sejak lama perempuan menjadi pusat perhatian pengarang sastra. Saat ini banyak bermunculan sastrawan yang menulis pandangan terhadap perempuan, salah satunya, Ratna Sarumpaet yang merupakan penulis perempuan yang mengangkat masalah gender dalam karyanya, yaitu naskah drama Pelacur dan Sang Presiden. Ratna Sarumpaet adalah seorang pengarang perempuan yang berpandangan modern dengan menggunakan seksualitas sebagai media untuk mengungkapkan masalah gender. Ratna Sarumpaet besar di Jakarta dan menamatkan kuliah di Fakultas Teknik Universitas Kristen Indonesia dan menjadi seorang sastrawan yang membuatnya berpandangan luas terhadap seksualitas dan feminisme, Ratna Sarumpet juga menggeluti dunia seni dan teater yang menuangkan pandangannya tentang 
ketidakadilan gender dalam setiap karyanya.

Berdasarkan uraian di atas, naskah drama Pelacur dan Sang Presiden karya Ratna Sarumpaet menganalisis bentuk ketidakadilan gender dengan menggunakan kajian sastra feminisme untuk mengetahui ketidakadilan gender terhadap perempuan dalam naskah drama tersebut. Selanjutnya, hasil penelitian ini akan dimanfaatkan sebagai alternatif pembelajaran sastra pada mata pelajaran Bahasa Indonesia di SMA. Oleh sebab itu, perlu adanya sebuah kajian yang lebih luas tentang ketidakadilan gender khususnya dalam Naskah Drama Pelacur dan Sang Presiden dengan judul "Citra Perempuan dalam Naskah Drama Pelacur dan Sang Presiden karya Ratna Sarumpaet dan Relevansinya pada Pembelajaran Sastra di SMA.

Berdasarkan latar belakang, penelitian ini bertujuan untuk 1) Mendeskripsikan bentuk-bentuk ketidakadilan gender dalam naskah drama Pelacur dan Sang Presiden karya Ratna Sarumpaet dan 2) Mendeskripsikan alternatif bahan ajar pada naskah drama Pelacur dan Sang Presiden karya Ratna Sarumpaet terhadap mata pelajaran Bahasa Indonesia di Sekolah Menengah Atas.

\section{METODE PENELITIAN}

Metode yang digunakan dalam penelitian ini yaitu pendekatan penelitian kualitatif karena penelitian yang dilakukan menghasilkan data berupa kata-kata atau kalimat yang bertujuan untuk mengungkapkan fenomena tentang apa yang diteliti dan penelitian ini juga menggunakan jenis penelitian deskriptif yaitu penelitian yang berusaha untuk mendeskripsikan suatu masalah yang akan diteliti. Penelitian kualitatif disebut sebagai metode penelitian naturalistik karena penelitiannya dilakukan pada kondisi alamiah (natural setting). Objek yang alamiah adalah objek yang berkembang apa adanya, tidak dimanipulasi oleh peneliti dan kehadiran peneliti tidak memengaruhi dinamika objek tersebut (Sugiyono, 2010: 8). Selain itu laporan hasil penelitian berisi kutipankutipan data dalam bentuk kata-kata maupun kalimat untuk memberikan gambaran deskripsi laporan.

Sumber data yang dihasilkan dalam penelitian ini berasal dari dialog (ungkapan) dari tokoh naskah drama Pelacur dan Sang Presiden karya Ratna Sarumpaet dengan tebal halaman 119 yang diterbitkan langsung oleh penulis Ratna Sarumpaet pada tahun 2009.

Penelitian ini tidak terikat pada suatu tempat, karena penelitian ini berbentuk teks sastra bisa dilakukan di mana saja. Instrumen penelitian utama adalah peneliti sendiri dan penelitian ini dibantu tabel untuk membantu mengumpulkan data.

Teknik pengumpulan data dalam penelitian ini berupa teknik dokumentasi dan teknik pustaka yaitu untuk mengumpulkan data dan mendapatkan landasan teori yang dijadikan sebagai pedoman untuk memecahkan masalah yang diteliti.

Analisis data dalam penelitian ini dilakukan dengan cara membaca naskah drama secara keseluruhan dan berulangulang, menyiapkan instrumen analisis ketidakadilan gender terhadap tokoh perempuan dalam naskah drama Pelacur dan Sang Presiden, memberi tanda atau kode seperti menggaris bawahi pada setiap kata-kata atau kalimat yang terdapat kesetaraan gender, setelah data terkumpul barulah menyimpulkan hasil dari penelitian tersebut. 


\section{HASIL PENELITIAN DAN PEMBAHASAN}

\section{Hasil Penelitian}

Tabel 1 Bentuk-Bentuk Ketidakadilan Gender

\begin{tabular}{|c|c|c|c|c|}
\hline No & $\begin{array}{c}\text { Bagian Isi Naskah } \\
\text { Drama }\end{array}$ & Kutipan Data & Hal & $\begin{array}{c}\text { Bentuk Ketidakadilan } \\
\text { Gender }\end{array}$ \\
\hline 1. & $\begin{array}{lr}\text { Pelacur dan } \begin{array}{r}\text { Sang } \\
\text { Presiden }\end{array} & \text { bagian } \\
\text { Pemberontakan } & \end{array}$ & $\begin{array}{l}\text { Dua tangan ini sudah berlumur darah sejak aku } \\
\text { masih kanak-kanak. Dan aku tidak mampu } \\
\text { membersihkannya. Dia sepert ditakdirkan untuk } \\
\text { terus menerus berlumur darah. Untuk terus } \\
\text { menerus kotor dan menagih. Siapa yang } \\
\text { menginginkanku menjadi pelacur? Siapa yang } \\
\text { mengotoriku.. siapa yang memupuk kebencian di } \\
\text { dadaku? Siapa? }\end{array}$ & 118 & $\begin{array}{l}\text { Dari aspek perempuan } \\
\text { sebagai objek dan cita } \\
\text { diri }\end{array}$ \\
\hline 2. & $\begin{array}{l}\text { Pelacur dan Sang } \\
\text { Presiden bagian } B u \text { Ria }\end{array}$ & $\begin{array}{l}\text { Penghuni penjara ini bukan Cuma kamu Mila. } \\
\text { Mimpi buruk,itu biasa. Jadi gak usah teriak- } \\
\text { teriak. Membunuh seorang pejabat tinggi mampu, } \\
\text { menghadapi mimpi buruk kok seperti orang } \\
\text { kesurupan. }\end{array}$ & 11 & $\begin{array}{l}\text { Dari aspek perempuan } \\
\text { menurut } \\
\text { orang lain. }\end{array}$ \\
\hline 3. & $\begin{array}{l}\text { Pelacur dan Sang } \\
\text { Presiden bagian Bu } \\
\text { Darno ke Pelacuran. }\end{array}$ & $\begin{array}{l}\text { Apa ini? Solidaritas? Bu Darno yang kejam yang } \\
\text { telah dengan sadis menempeleng Jamila yang } \\
\text { cantik dan lemah lembut. Kita punya aturan } \\
\text { disini. }\end{array}$ & 53 & $\begin{array}{l}\text { Dari aspek Kekerasan } \\
\text { dan Tidak Bernilai. }\end{array}$ \\
\hline 4. & $\begin{array}{l}\text { Pelacur dan Sang } \\
\text { PresidenUngkapan } \\
\text { Jamila }\end{array}$ & $\begin{array}{l}\text { Berusia } 13 \text { tahun, agar aku bisa dibodoh-bodohi. } \\
\text { Ha ha hahaha, aku berusia } 22 \text { tahun dan aku } \\
\text { tidak murni seorang PSK. Aku pekerja seks } \\
\text { peneliti. }\end{array}$ & 80 & $\begin{array}{l}\text { Dari aspek beban kerja } \\
\text { ganda }\end{array}$ \\
\hline
\end{tabular}

\section{PEMBAHASAN}

\section{Bentuk-Bentuk Ketidakadilan Gender}

a. Ketidakadilan Gender dari Aspek Perempuan sebagai Objek dan Citra Diri

Perempuan sebagai objek dan citra diri merupakan suatu anggapan terhadap gender atau penilaian terhadap suatu gender bahwa gender memiliki nilai peran yang berbeda-beda di masyarakat. Sampai saat ini, dalam kehidupan sehari-hari, masih ada peristiwa ketidakadilan terhadap perempuan, namun ada sebagian masyarakat yang menentang dan ada juga sebagian lain yang setuju bahwa suatu gender sebenarnya untuk peran tertentu saja. Adanya anggapan bahwa perempuan itu tidak penting, hal tersebut membuat kaum perempuan merasakan ketidakadilan pada diri mereka.

Bentuk ketidakadilan yang dialami oleh tokoh Jamila dari aspek citra diri dapat dilihat melalui kutipan teks naskah drama berikut ini.

"Apa ini. Ya Allah apa ini

Ibu menyebut kelahiranku adalah cahaya. Disambut dengan upacara, diiringi doa dan salawat Nabi. Ibu berbicara tentang kesucian dan harga diri. 
Dan aku disini sekarang Bu. Berdiri sendirian, ditengah kegelapan yang pekat yang tak punya ujung.

Kesucian seperti apa Bu? Harga diri yang bagaimana?"

Dari kutipan tersebut dikatan bahwa betapa tidak berdayanya Jamila untuk mencari tahu kedudukannya saat itu menjadi perempuan yang seperti apa. Pribadi individu Jamila yang terlempar keluar dari tujuan hidupnya. Seperti pada kutipan, Jamila bertanya-tanya akan kesucian dan harga diri dari masa lalu ibunya. Dijelaskan bahwa perempuan sebenarnya ingin dirinya memiliki kesucian dan harga diri. Kesucian dari lahir dan dapat dijaga saat dewasa kelak. Namun, takdir Jamila berkata lain, kesucian dan harga diri yang ia punya hancur karena perbudakan budaya yang diperdagangkan.

\section{b. Ketidakadilan Gender dari Aspek Perempuan Menurut Padangan Orang Lain}

Secara umum aspek yang menjelaskan pandangan terhadap orang lain berkaitan dengan citra sosial dengan melihat orang lain berdasarkan apa yang dia lihat dan apa yang dia pikirkan. Pandangan itu bisa dari siapa saja mengenai siapa orang yang kita nilai.

Bentuk pandangan terhadap orang lain yang dialami Jamila dapat dilihat melalui kutipan teks naskah drama berikut ini.

"Pelacur, pembunuh, dan sekarang siap jadi martir. Kamu itu pelacur Mila, kamu pembunuh. Jadi jangan kamu bermimpi ingin jadi pahlawan. Politik.. politik. (Hal 27)

Pada kutipan di atas terdapat ketidakadilan gender terhadap perempuan dari aspek pandangan orang lain karena pada kutipan tersebut merupakan pandangan orang lain terhadap Jamila yang tidak baik dan dipandang rendah akibat statusnya sebagai pelacur. Jamila tidak punya pilihan karena pada saat itu ia dijual oleh ayahnya sendiri. Hal tersebut membuat perempuan mengalami gangguan psikis dan merasa hina sepanjang hidupnya.

\section{c. Ketidakadilan Gender dari Aspek Kekerasan dan Tidak Bernilai}

Kekerasan merupakan bentuk serangan yang baik berupa fisik atau non fisik. Kekerasan yang terjadi pada sesama manusia biasanya banyak faktor yang menyebabkan terjadinya kekerasan. Ada kekerasan sesama jenis dan kekerasan berlawanan jenis contohnya seperti kekerasan pada perempuan sehingga membuat perempuan itu tidak bernilai harga dirinya serta martabatnya. Maka dari itu banyak sekali bentuk-bentuk kekerasan yang terjadi pada kaum perempuan dan merendahkan perempuan menjadi perempun tidak berharga.

Bentuk ketidakadilan yang dialami oleh tokoh Jamila dari aspek kekerasan dan tidak bernilai dapat dilihat melalui kutipan teks naskah drama berikut ini.

"Forum Pembela Iman Bangsa atau FPIB, besok akan mengerahkan ribuan massanya ke depan Kantor Pengadilan, memastikan sidang Pengadilan menjatuhi Jamila hukuman mati.

"Forum Pembela Iman Bangsa. Milisi moralis munafik itu.

Kalau saja mereka mengerti apa itu moral. Mereka akan tau moral seperti apa yang membuat nasibku jadi seperti ini, dan mereka seharusnya mengangkatku menjadi anggota kehormatan”. (Hal 21)

Kutipan di atas merupakan bentuk kekerasan secara halus dan dapat dikatakan ketidakadilan perempuan yang dirasakan oleh Jamila. Ia merasakan penderitaan setelah ia dijual oleh ayahnya ke mucikari pada saat itu.

d. Ketidakadilan Gender dari Aspek Beban Kerja Ganda/ Perempuan Sebagai Objek Utama

Adanya anggapan bahwa kaum perempuan memiliki sifat memelihara dan rajin, serta tidak cocok untuk menjadi kepala rumah 
tangga, berakibat bahwa semua pekerjaan domestik rumah tangga menjadi tanggung jawab kaum perempuan. Memiliki beban ganda seperti mengurus keluarga dan pekerjaan lainnya. Namun, anggapan seperti itulah yang membuat perempuan tidak bisa maju pada jaman itu. Hal ini disebabkan adanya ketidakadilan gender.

Bentuk ketidakadilan yang dialami oleh tokoh Jamila dari aspek beban kerja ganda dapat dilihat melalui kutipan teks naskah drama berikut ini:

"Tapi saya ingin punya banyak uang Bu. Saya ingin menyekolahkan adik saya. Saya tidak mau adik saya, sama seperti saya. (hal 27 )"

"Ooooo, jadi itu intinya. Ingin punya banyak uang? Bagus. Ibu akan menunjukan sama kamu, membimbing kamu, hingga kamu dengan cara gampang, cepat, enak, dan dapat uang sebanyak-banyaknya. (hal 27 )"

Dari dua kutipan di atas tokoh Jamila bekerja untuk mencari nafkah. Tokoh Jamila 1 harus memikul beban kerja ganda walau ia terjerumus ke pekerjaan yang salah, tetapi demi adiknya ia rela melakukan apa saja. Ini dikarenakan keluarganya tidak berkecukupan Jamila 1 terpaksa harus membantu mencari uang untuk kebutuhan sehari-hari. Mencari nafkah adalah tugas seorang laki-laki sebagai kepala rumah tanggga. Hal ini membuat ibu sebagai kaum perempuan mengalami beban kerja. Dijelaskan pula bahwa Jamila adalah korban perdagangan anak demi kebutuhan hidupnya dan keluarganya. Seharusnya perempuan tidak seharusnya mencari nafkah untuk keluarga, ini merupakan bentuk ketidakadilan gender terhadap perempuan.

\section{Alternatif Naskah Drama Pelacur dan Sang Presiden sebagai Bahan Ajar di Sekolah Menengah Atas}

Terdapat beberapa aspek untuk menjadi bahan ajar di Sekolah. Berikut akan dijelaskan ketiga aspek yang terdapat dalam naskah drama Pelacur dan Sang Presiden karya Ratna Sarumpaet.
Pertama, dilihat dari bahasa yang digunakan Ratna Sarumpaet dalam naskah drama yang ditulisnya. Ratna menggunakan bahasa yang terkesan vulgar dalam setiap karyanya, seperti kutipan berikut.

"Saya masih akan tetap melacur bu Darno.Tapi saya akan menjadi pelacur sesuai dengan keinginan saya (hal. 57)"

Berdasarkan kutipan tersebut, dari sudut bahasa yang digunakan Ratna Sarumpaet menggunakan bahasa yang terkesan vulgar. Walaupun naskah drama yang digunakan terkesan vulgar, naskah ini bisa dijadikan sebagai bahan ajar pada tingkat Sekolah Menengah Atas. Hal ini disebabkan pada tingkat SMA masa usia siswa-siswi sudah terhitung remaja menuju dewasa (17-18 an). Mereka sudah bisa mengerti dan sudah bisa memahami bahasa yang cukup rumit. Selain itu pada usia merekapun seharusnya diajarkan tentang pentingnya seks educationi.

Kedua, dari segi kematangan jiwa (psikologi), berdasarkan isi naskah drama Pelacur dan Sang Presiden yang mengangkat seksualitas menggunakan bahasa yang vulgar. Secara psikologi naskah drama Pelacur dan Sang Presiden dapat dipahami oleh siswa karena sangat bermanfaat untuk mengetahui pendidikan tentang perempuan itu sendiri. Untuk mempelajari mana yang benar dan mana yang salah siswa sudah bisa untuk memutuskannya. Oleh karena itu, naskah drama ini bisa diterapkan sebagai bahan ajar sastra pada Sekolah Menengah Atas.

Adapun bentuk seksualitas dalam naskah drama Pelacur dan Sang Presiden seperti terlihat pada kutipan berikut:

"Hei Gendut sini kamu!

Kenapa Pak? Mau coba? Huu betulkan saya laris, (hal. 46-47)"

Ketiga, latar belakang budaya, dilihat dari segi latar belakang budaya naskah drama Pelacur dan Sang Presiden menceritakan tentang sejarah perdagangan anak di Indonesia, seperti pada kutipan berikut. 
"Ayahmu menjualmu ke mucikari saat kamu masih ingusan. Dalam keadaan sekarat Ibumu menculikmu dari mucikari itu dan mengantarmu kemari supaya kamu aman. Di rumah keluarga terhormat seperti di rumah ini dia berharap kamu akan tumbuh sehat. Dan apa yang kamu lakukan? Kamu seolah ditakdirkan untuk menjadi pelacur. (hal. 7).

Kutipan di atas menceritakan tentang sejarah Indonesia. Selain menceritakan tentang sejarah Indonesia naskah drama ini juga menceritakan tentang latar budaya kehidupan bebas yang dipilih oleh tokoh Enrico, seperti kutipan berikut:

"Supaya kalian bisa goyang sampai pagi. Supaya kalian bisa melahap sepuluh lakilaki dalam satu malam. Supaya kalian cepat kaya, lalu keluar dari hutan sialan ini dengan sekoper uang. (hal. 79)"

Meskipun latar budaya dalam naskah drama Pelacur dan Sang Presiden menceritakan tentang kehidupan bebas dan juga termasuk dalam hal seksualitas, naskah drama ini bisa dijadikan sebagai bahan ajar pada tingkat Sekolah Menengah Atas. Ini disebabkan siswa sudah terhitung remaja menuju dewasa, sudah bisa menilai dan memberikan kesimpulan terhadap sesuatu yang terjadi baik di kehidupan nyata maupun dalam karya sastra.

Ketiga aspek bahan pengajaran satra yang sudah diuraikan di atas yaitu bahasa yang digunakan, kematangan jiwa, dan latar belakang budaya pada naskah drama Pelacur dan Sang Presiden karya Ratna Sarumpaet. Hasil penelitian ini akan diterapkan sebagai bahan ajar pada mata pelajaran Bahasa Indonesia di Sekolah Menengah Atas.

Berdasarkan hasil analisis terhadap masalah gender dalam naskah drama Pelacur dan Sang Presiden dengan menggunakan kajian sastra feminis, peneliti akan melampirkan lembar kerja mahasiswa yang sudah lengkap dengan bentuk informasi dan komponen yang ada dalam bahan ajar. Sesuai dengan teori
Penelitian ini cocok untuk dijadikan sebagai bahan ajar berbentuk Lembar Kerja Siswa (LKS) di Sekolah Menengah Atas. Lembar kerja mahasiswa yang peneliti buat sesuai dengan format Rencana Pelaksanaan Pembelajaran (RPP) mata pelajaran Bahasa Indonesia materi pembelajaran Drama. Bentuk bahan ajar yang peneliti buat terdapat capaian pembelajaran yang menjadi tujuan akhir dari kegiatan pembelajaran, kompetensi yang harus dikuasai siswa setelah menyelesaikan pertemuan dalam mempelajari satu pokok bahasan, selanjutnya keterampilan berpikir yang dituntut, uraian materi, aktivitas yang harus dilakukan selama pembelajaran untuk mencapai kompetensi, dan yang terakhir referensi.

\section{SIMPULAN}

Berdasarkan hasil penelitian dan pembahasan tentang ketidakadilan gender pada tokoh perempuan dalam naskah drama Pelacur dan Sang Presiden karya Ratna Sarumpaet, terdapat beberapa bagian-bagian di dalam naskah drama tersebut. Naskah drama ini juga dapat dijadikan sebagai alternatif bahan ajar di Sekolah Menengah Atas. Adapun kesimpulan dari pembahasan ketidakadilan gender dan alternatif bahan ajar di Sekolah sebagai berikut:

Bentuk-bentuk ketidakadilan gender pada tokoh perempuan dalam naskah drama Pelacur dan Sang Presiden karya Ratna Sarumpaet terdapat pada beberapa bagian dalam naskah drama tersebut. Pertama, bentuk ketidakadilan gender dari aspek perempuan sebagai objek dan citra diri yang terdapat pada dua bagian di dalam naskah drama Pelacur dan Sang Presiden. Kedua, bentuk ketidakadilan gender dari aspek perempuan menurut pandangan orang lain atau pelabelan negatif yang terdapat pada empat bagian di dalam naskah drama Pelacur dan Sang Presiden. Ketiga, bentuk ketidakadilan gender dari aspek kekerasan dan tidak 
bernilai yang terdapat pada empat bagian di dalam naskah drama Pelacur dan Sang Presiden. Keempat, ketidakadilan gender dari aspek beban kerja ganda atau perempuan sebagai objek utama yang terdapat pada satu bagian di dalam naskah drama Pelacur dan Sang Presiden.

\section{REFERENSI}

Balai Bahasa Provinsi Kalimantan Barat (2005).

Damono, Sapardi Djoko. (2015). Suti. Jakarta: PT Kompas Media Nusantara.

Djajanegara, Soenarjati. (2000). Kritik Sastra Feminis Sebuah Pengantar. Jakarta: Gramedia Pustaka Utama.

Endraswara, Suwardi. (2014). Metode Pembelajaran Drama.Yogyakarta: CAPS.

Fahmi, Ridzky Firmansyah.(2017) Pembelajaran Naskah Drama Melalui Bedah Naskah. Jurnal Forum Didaktik Vol. I No. 1.

Fakih, Mansor. (2013). Analisis Gender dan Tranformasi Sosial. Yogyakarta: Pustaka Pelajar

Nurgiyantoro, Burhan. (2015). Teori Pengkajian Fiksi. Yogyakarta: Gadjah Mada University Press.

Purwanto, Joko. (2016). Analisis feminisme dalam naskah drama monolog 'Marsinah Menggugat' karya Ratna Sarumpaet. Jurnal Bahtera Vol 3, No 05 http://ejournal.umpwr.ac.id/index.p $\mathrm{hp} / \mathrm{bahtera/article/view/5054}$

Ratna, Kutha I Nyoman. (2004). Teori, Metode dan Teknik Penelitian Sastra. Yogjakarta : Pustaka Pelajar Sarumpaet, Ratna. (2006). Pelacur dan Presiden.

Sugihastuti dan Suharto. (2005). Kritik Sastra Feminis Teori dan Aplikasinya. Yogjakarta: Pustaka Pelajar
Sugiyono. (2010). Metode Penelitian Kuantitatif, Kualitatif dan $R \& D$. Bandung: ALPABETA.

Waluyo, Herman J. (2003). Drama Teori dan Pengajarannya. Yogyakarta: PT Hanindita Graha Widia.

Wellek, Renne dan Austin Warren. (1995). Teori Kesusastraan. (Terjemahan Melani Budianta). 